\title{
次世代脳血管内治療のための弁付きハイブリッドフラクタルステントの研究
}

\author{
市川 明彦*1，伊藤 隆博 ${ }^{* 2}$ ，下垣外 浩平 ${ }^{* 2}$ ，久保 貴 ${ }^{* 1}$ ，福田 敏男 ${ }^{* 1,}{ }^{* 3,{ }^{*} 4}$
}

\section{The study of valve hybrid fractal stent for the next generation brain intravascular treatment}

\author{
Akihiko ICHIKAWA ${ }^{* 1}$, Takahiro ITO ${ }^{* 2}$, Kouhei SHIMOGAITO*2 ${ }^{* 2}$ Takashi KUBO $^{* 1}$ \\ and Toshio FUKUDA ${ }^{* 1}, * 3, * 4$ \\ ${ }^{* 1}$ Department of Mechatronics engineering, Meijo University \\ 1-501 Shiogamaguchi, Tenpaku-ku, Nagoya-shi, Aichi 468-8502, Japan \\ ${ }^{* 2}$ Department of Mechanical Engineering, Meijo University \\ 1-501 Shiogamaguchi, Tenpaku-ku, Nagoya-shi, Aichi 468-8502, Japan \\ ${ }^{* 3}$ Institute for Advanced Research, Nagoya University \\ Furo-cho, Chikusa-ku, Nagoya-shi, Aichi 464-8601, Japan \\ ${ }^{* 4}$ School of Mechatronic Engineering, Beijing Institute of Technology \\ 5 Yiheyuan Rd, Haidian, Beijing, China
}

\section{Received 23 November 2014}

\begin{abstract}
We developed a valve hybrid fractal stent to treat the cerebral aneurysm what is one of a cerebrovascular disease. The stent has a valve part to path through a coil. The valves have fractal structures. So, the blood flowing into cerebral aneurysm is prevented. We performed a Particle Image Velocimetry (PIV) experiment to evaluate the inflow into cerebral aneurysm. By the experiment result, we visualized the stream line by using the cerebral aneurysm. By calculation, we succeeded in a reduction in the inflow by using the valve fractal stent.
\end{abstract}

Key words : Cerebral aneurysm, Stent, Coil embolization, Flow diverter, Particle Image Velocimetry (PIV)

\section{1. 緒言}

本研究では，動脈瘤の中での脳血管に発生する脳動脈瘤に注目し，新たな治療デバイスの研究を行う。現在， 世界全体の死亡原因の 1 位， 2 位が心疾患及び脳血管疾患となっている。血管疾患には，代表的な症状が 2 例あ り，ひとつが血管閉塞，もうひとつが動脈瘤である．脳動脈瘤の治療法には，従来開頭手術によるクリッピング が行われてきた.しかし，開頭手術は，患者への負担が大きく長入院が必要である. そこで，低浸襲医療として， 大腿部の血管からカテーテルと呼ばれる細い筒を用い，その中をステントと呼ばれる金属管やコイルと呼ばれる 細い金属を用いて，開頭手術を行うこと無く血管治療を行う手法が開発されている(Armoiry, et al., 2012, Benndorf, et al., 2001, Doerfler, et al., 2004, Hurst and Vassilicos, 2007, Kim, et al., 2010). コイル治療は，低侵襲医療であるので

No.14-00635 [DOI:10.1299/transjsme.14-00635], J-STAGE Advance Publication date : 29 September, 2015

*1 正員，名城大学（干468-8502＼cjkstart愛知県名古屋市天白区塩釜口 1-501）

*2 名城大学 理工学部

*3 名古屋大学 (T464-8601 愛知県名古屋市 千種区不老町)

*4 北京大学 (5 Yiheyuan Rd, Haidian, Beijing, China)

E-mail of corresponding author: ichikawa@mrijo-u.ac.jp 
患者への負担は少ないが，血栓の生成・剥離やコイルの血管内一の流出といったように問題点がある. そこで提 案されたのが，フローダイバーティングステントである.

フローダイバーティングステントとは, ステントの表面が非常に網目が細かい構造のステントで, これにより， フローダイバータ効果を得ている. フローダイバータ効果とは, 流体の流れを制御し, 任意の方向へ向けるもの である．これにより，脳動脈瘤内一の血液の流入を抑えることが出来る(Ku, et al., 1985, Lubicz, et al., 2010, Lylyk, et al., 2002, Lylyk, et al., 2009, Malek, et al., 1999). しかし，フローダイバーティングステントを留置しても尚死亡者 が発生している，そのため，脳動脈瘤に対する新たな医療デバイスの研究が必要である.

このような課題に対して, 従来我々は, ステント治療とコイル治療の併用を目的としたフラクタルステントに ついて研究を行ってきた(Kojima, et al., 2012a, Kojima, et al., 2012b). フラクタルステントは，ステントの表面形状 がフラクタル構造になっている. フラクタル構造を用いることで, フローダイバータ効果を得ることができる. また, コイル治療用の穴からコイル治療の併用が可能であり, より確実な治療を行うことが可能である. しかし, フラクタルステントには, 問題点が 2 点ある. フラクタルステントは, コイル治療の併用のためにカテーテル挿 入用の穴がある，この穴が脳動脈瘤のネック(入口)の大きさによっては，血液が脳動脈瘤内に多量に流れ込んで しまい, フラクタルステントのフローダイバータ効果を阻害してしまい, その効果を十分に機能しない可能性が ある.これは，脳動脈瘤のネックの大きさが患者ごとに違うため，発生する問題である．また，フラクタルステ ントは, カテーテル挿入用の穴と脳動脈瘤のネックの位置を合わせるのが困難であるため, カテーテルによるコ

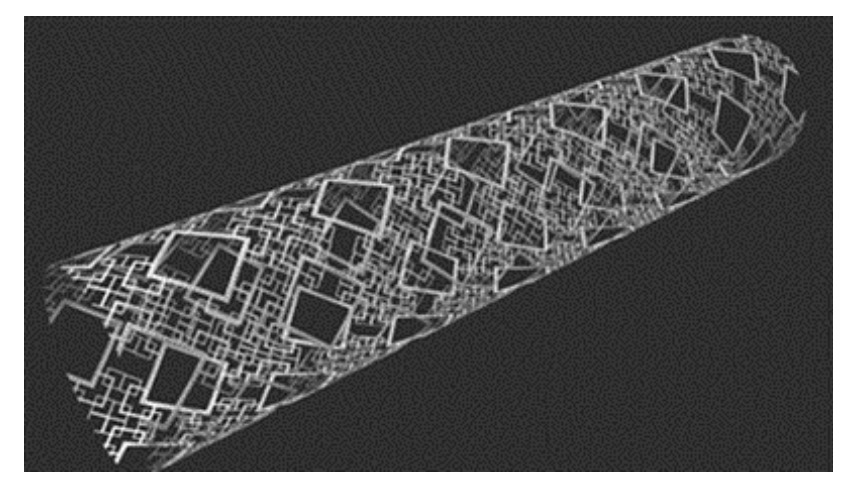

Fig.1 Over view of the Fractal Stent. This stent is used for hybrid operation with a stent and a coil.

イル治療の併用が行えない可能性がある.このように，フラクタルステントは，フローダイバータ効果とコイル 治療の併用といった機能が十分に発揮されない可能性がある.

そこで, 本研究では, 脳血管疾患の脳動脈瘤の治療を目的とした新たな, 血管内治療のデバイスとして, 弁付 きフラクタルステントを提案する. 本稿では, それらまた, 弁付きフラクタルステントの設計と試作を行い, そ の有用性を検証する.

\section{2. 弁付きハイブリッドフラクタルステント}

弁付きフラクタルステントとは，我々が新たに提案したステントであり，コイル治療の併用のためのカテーテ ル挿入用の穴に開閉弁を取り付けたステントである.コイル治療を併用する場合は，カテーテルで開閉弁を押寸 ことで，開閉弁が開き，脳動脈瘤内にカテーテルが入ることで治療を行う。これにより，フラクタルステントの 問題点であるカテーテル挿入用の穴からの血液の流入を防ぐことができる.

ここで，血液の流入を防ぐために，例えば単に側面に全く穴が開いていない円筒状のステントについて問題点 を述べる，通常血流を抑えるためには，まったく穴が開いていない円筒管にて動脈瘤を塞ぐことが最も血流を抑 えることが可能である. しかし，ステント治療を行った際，ステントが異物と認識され血栓が血管内に生じるた め, 留置したステントが血管内表面にある血管内皮細胞によって覆われ埋没することにより, 治療が完了する. 血管内皮細胞がステント表面を覆うまでの間, ステント表面に血栓が生成されないように抗血栓薬を服用しなけ ればならない，また，血管内の動脈瘤部分以外の血管分岐先に血流が届かないことも考えられ，ステントは適度 
Ichikawa, Ito, Shimogaito, Kubo and Fukuda, Transactions of the JSME (in Japanese), Vol.81, No.830 (2015)

に血流が通過する必要がある，一般的には，3 ケ月程で血管内皮細胞がステント表面を完全に覆うが，円管ステ ントの場合，ステントの表面積が通常のステントよりも大きいため，血管内皮細胞がステント表面を完全に覆う までに時間がかかってしまう．血管内皮細胞がステント表面を覆うまでの期間が長期化すると，抗血栓薬の副作 用により，内出血をしても血液が凝固せず，失血死に至るなど他の症状が発生する恐れがある．このように，円 管ステントは，フラクタルステントの問題を解決したが，ステント留置後に服用寸る抗血栓薬による副作用が問 題になる. 
本研究で我々が新たに提案する弁付きフラクタルステントとは，弁付きステントの開閉弁の部分をフラクタル 構造にしたステントである. 図.2 に弁付きフラクタルステントの概要を示す. 弁付きフラクタルステントは, 弁 付きステントの開閉弁の部分にフラクタル構造を作成したものである. フラクタル構造を用いることで，流体の

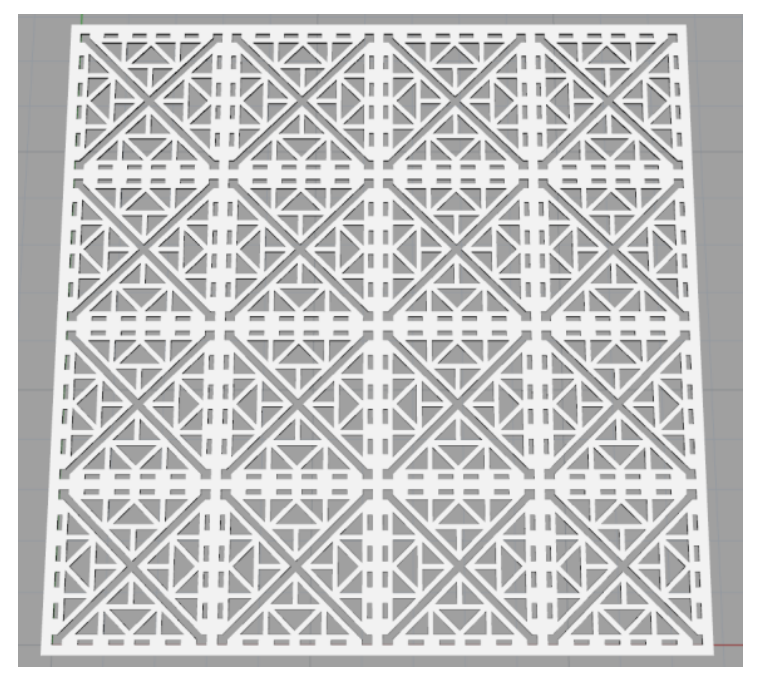

(a) Valve hybrid fractal stent sheet

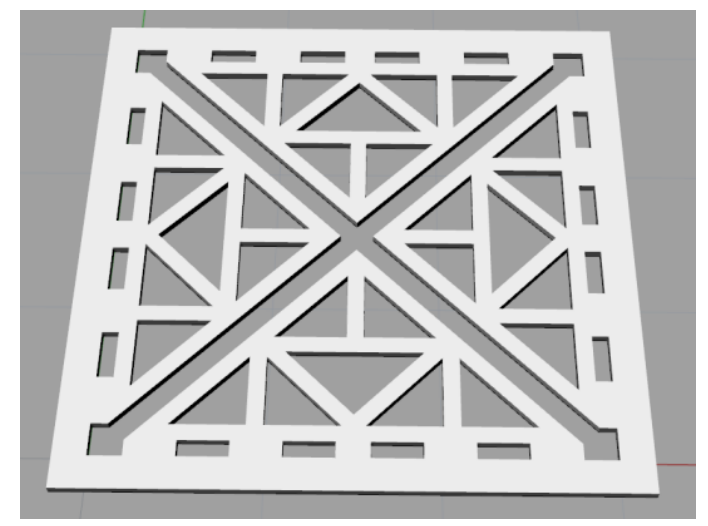

(b) Valve hybrid fractal stent enlarged view

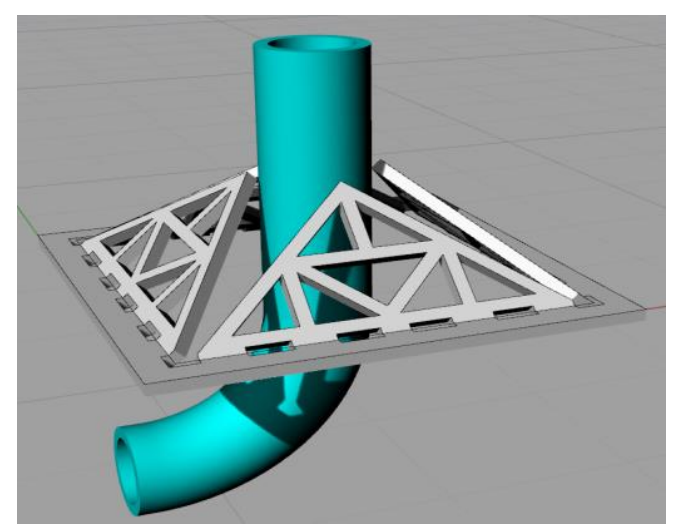

(c) Activation of the valve with catheter

Fig.2 Model of the valve hybrid fractal stent. This stent has a valve mechanism for through a catheter.

影響を抑えつつ，血管内被細胞と隣接する面積が増え，血管内皮細胞が弁付きフラクタルステントを覆いやすく しており，これにより，血管内皮細胞への早期埋没を狙う。これにより，従来のフラクタルステントの問題点で あった動脈瘤ネックとコイル用穴，及び，血管内皮細胞への埋没の遅延を改善できると考えられる. 


\section{3. 弁付きフラクタスステントの PIV 実験}

\section{$3 \cdot 1$ 弁付きフラクタルステントの作成}

作成した弁付きフラクタルステントを図 3 に示す。本研究では，弁付きフラクタルステントの流体抑制の効果 を観察するため，ステントは円筒形状ではなく，観察用のモデルに配置しやすいよう平面のままで用いる.

作成方法として，厚み $0.05[\mathrm{~mm}]$ の SUS310 板にエッチングにてフラクタルパターンを作成した. 通常のステン トでは，レーザ加工機にて，ニッケル-チタンの形状記憶合金を用いる．しかしながら，レーザ加工機では本論 文で用いるフラクタル構造の作成は困難である。 また，ニッケル-チタンはエッチングでの加工が難しく，本研 究ではフラクタル形状による効果を確認するために SUS 素材を用いている.

ここで，血流に対して弁構造部分が開閉しないことを確認する必要がある.図 3 の様に，弁構造部分の流体力

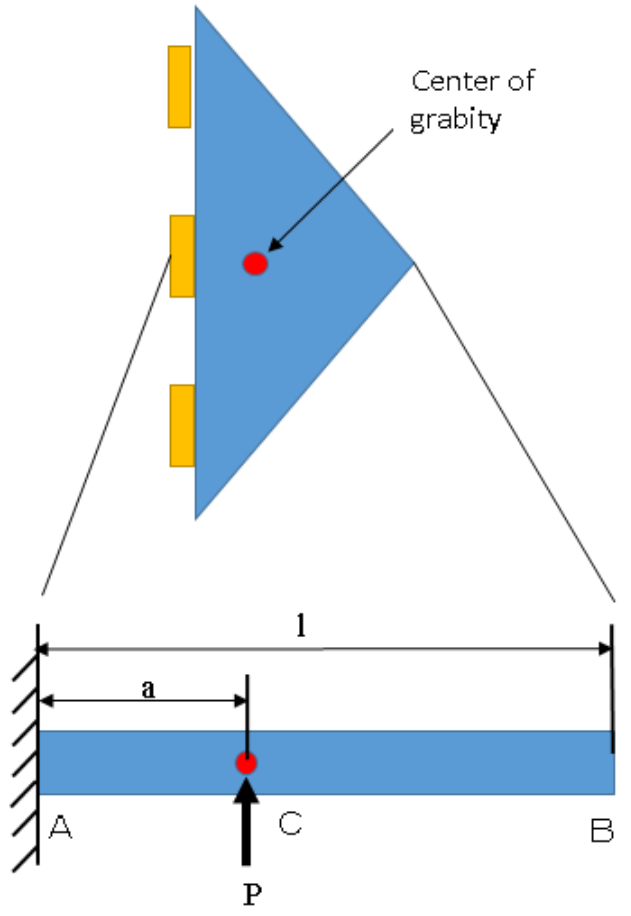

Fig.3. Schematic model of the valve fractal stent. The deflection is calculated by using beam model.

とヒンジ部分の数值解析モデルとして，等価のはり構造とした. ここで，1:はり長さ，a:重心までの長さ，P:重 心に作用する荷重， $\theta$ :たわみ角， $\mathrm{y}$ :たわみ， E:ヤング率，I：断面二次モーメントとする.

$\mathrm{C}$ 点周りのモーメントは, $\mathrm{M}=\mathrm{P} ・ \mathrm{a}$ なので,

$E I \theta_{1}=\int M d x+C_{1}$

$E I y_{1}=\int M x d x+C_{1}+C_{2}$

よって，C点のたわみとたわみ角は

$$
\begin{aligned}
& \theta_{C}=-\frac{P a^{2}}{2 E I} \\
& y_{C}=\frac{P a^{3}}{3 E I}
\end{aligned}
$$

$\mathrm{BC}$ 間は $\theta_{C}$ は一定なので，

$$
y_{2}=\theta_{C}\{\mathrm{x}-(\mathrm{l}-\mathrm{a})\}+y_{C}
$$

$\mathrm{X}=1$ でたわみは最大となるので,

$$
y_{\text {max }}=-\frac{P a^{2} \cdot(2 l+a)}{6 E I}
$$

血管内の圧力を $100[\mathrm{mmHG}]$ とすると，

$100[\mathrm{mmHG}]=133.32 \times 10^{3} \quad[\mathrm{~Pa}]=133.32 \times 10^{2}\left[\mathrm{~N} / \mathrm{m}^{2}\right]$

これが弁にかかるので，弁 1 枚の面積を $\mathrm{S}$ とすと重心にかかる荷重 $\mathrm{P}$ は,

$$
\begin{aligned}
& S=1.69 \times 10^{-6}\left(\mathrm{~m}^{2}\right) \\
& \mathrm{P}=133.32 \times 10^{2} \times 1.69 \times 10^{-6}=0.023 \quad[\mathrm{~N}]
\end{aligned}
$$

また，はりの断面二次モーメントは，厚さを $50[\mu \mathrm{m}]$ とすると， 
$\mathrm{I}=1.875 \times 10^{-5}$

また，ヤング率は, $3500\left[\mathrm{Kg} / \mathrm{mm}^{2}\right]$ とする.

よって，はりの最大たわみ量は，

$y_{\text {max }}=7.671 \times 10^{-5} \quad[\mathrm{~mm}]$

よって，弁付きステントは，血流のみではほとんどたわまないことが分かる.

また，フラクタル形状の設計について，図 4 に示す.フラクタルの流体抑制について，長田ら(Nagata, et al, 2013)によってフラクタルパターンのパラメータ及び後流相互作用長さスケール $X_{*} に よ り$ 効果範囲を計算により 求めることが可能である.

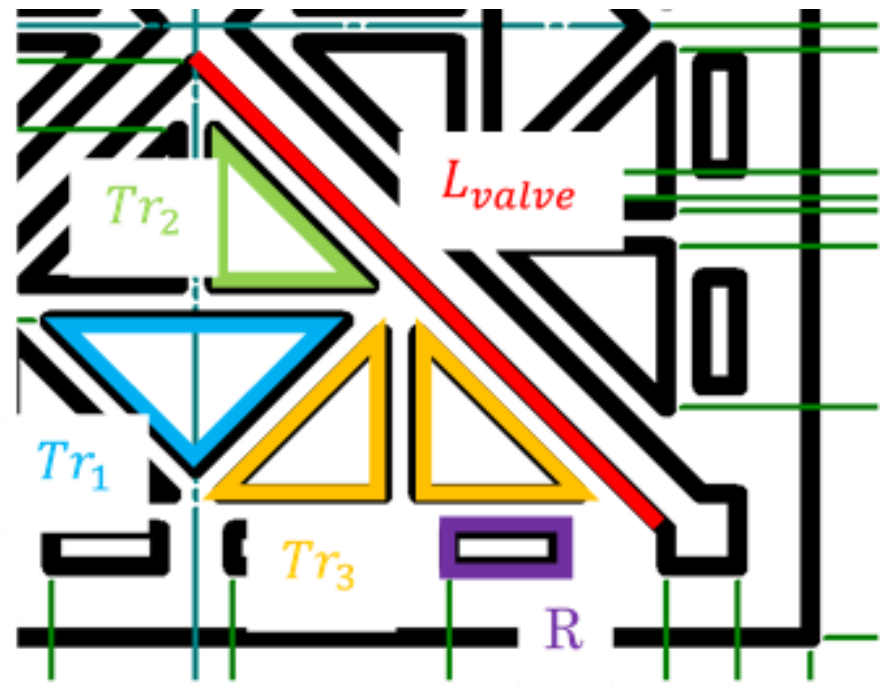

Fig.4 Schematic model of fractal pattern. These parameters decide the efficiency of the fractal effect.

Table 1Parameters of Fractal structure

\begin{tabular}{|l|l|}
\hline Cross-sectional side length: $\mathrm{T}$ & $3.4[\mathrm{~mm}]$ \\
\hline Inhibition rate: $\sigma$ & $0.65782[\%]$ \\
\hline Side length of the valve: $L_{v a l v e}$ & $1.838478[\mathrm{~mm}]$ \\
\hline Short side of Triangle $T r_{1}: T r_{1 s}$ & $0.579828[\mathrm{~mm}]$ \\
\hline Long side of Triangle $T r_{1}: T r_{1 l}$ & $0.82[\mathrm{~mm}]$ \\
\hline Short side of Triangle $T r_{2}: T r_{2 s}$ & $0.42[\mathrm{~mm}]$ \\
\hline Long side of Triangle $\operatorname{Tr}_{2}: T r_{2 l}$ & $0.59397[\mathrm{~mm}]$ \\
\hline Short side of Triangle $T r_{3}: T r_{3 s}$ & $0.445[\mathrm{~mm}]$ \\
\hline Long side of Triangle $T r_{3}: T r_{3 l}$ & $0.629325[\mathrm{~mm}]$ \\
\hline Short side of Rectangle R: $R_{s}$ & $0.1[\mathrm{~mm}]$ \\
\hline Grid thickness of the fluid direction: t & $0.1[\mathrm{~mm}]$ \\
\hline
\end{tabular}

以上より，後流相互作用長さスケール：

$$
X_{*}=L_{\text {valve }}{ }^{2} / t=\frac{1.838478^{2}}{0.1}=33.8
$$

効果メッシュサイズ :

$$
M_{\text {eff }}=\frac{4 T^{2}}{P} \sqrt{1-\sigma}=\frac{4 \times 3.4^{2}}{21.80184992} \sqrt{1-0.65782}=0.31064[\mathrm{~mm}]
$$

フラクタルからの距離を $\mathrm{X}(\mathrm{mm})$ として,$X_{X_{*}}=0.045$ 付近が効果の有無の境界である.

ここから， $X=0.045 X_{*}=0.045 \times 33.8=1.521[\mathrm{~mm}]$ より外の範囲で効果が得られると考えられる.動脈瘤は直径 $8 \mathrm{~mm}$ であり, 十分この範囲にはいるため, フラクタル効果が得られると考えられる. 
図 5 に作成した弁付きフラクタルステントを示す. MEMS で用いられるフォトリソグラフィのエッチング技術 により加工されており，素材として厚み $0.05[\mathrm{~mm}]$ の SUS301 を用い，表面にパターンをマスクしたのちにエッチ ヤントにて不要部分を溶解し作成した.

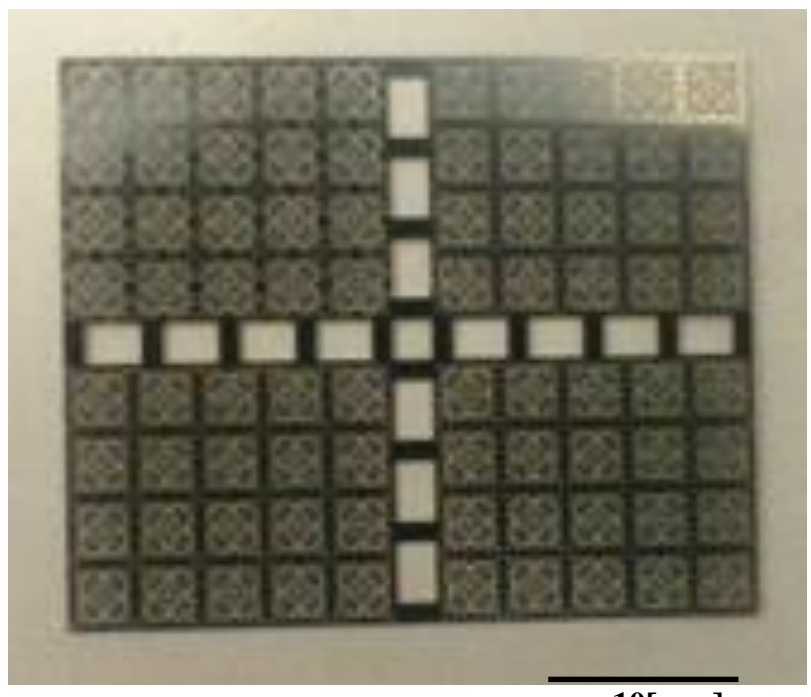

(a) Valve fractal stent sheet $\mathbf{1 0}[\mathbf{m m}]$

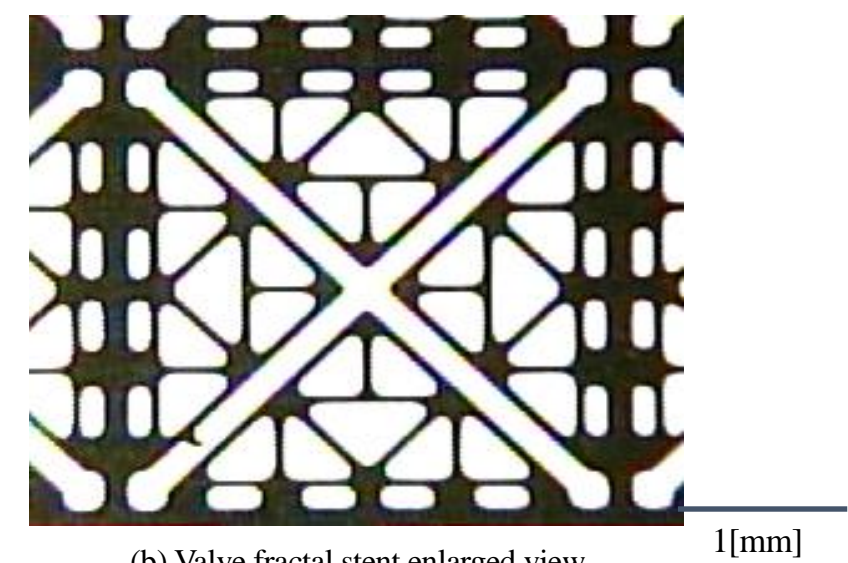

(b) Valve fractal stent enlarged view

$1[\mathrm{~mm}]$

Fig.5 Model of the valve fractal stent. The thickness of these stent is

$50[\mu \mathrm{m}]$. This sheet is fabricated by wet etching process.

\section{$3 \cdot 2$ 脳動脈瘤モデルの作成}

PIV での流体観察を行うためには，透明でかつ高精度の動脈瘤モデルが必要となる。そこで，本研究では，透 明な高分子ポリマーである PDMS（ポリジメチルシロキサン）を用いて動脈瘤のモデルを作成する. PDMS は透明 な高分子であり，高精度に型取りを行うことが可能であり。また，脳動脈瘤モデルの作成方法としては，3Dプ リンタを用いて ABS 樹脂で脳動脈瘤の型となるモデルを作成する．作成したモデルの表面は粗いため，アセト ンでモデルの型の表面を溶解させ滑らかにする．表面処理した脳動脈瘤モデルの型を PDMS で覆い，内部のモ デルの型をアセトンで完全に溶解させることで脳動脈瘤モデルを作成する．作成する脳動脈瘤モデルを図 6 に示 す。動脈瘤は，脳動脈瘤を想定し， $\phi 8[\mathrm{~mm}]$ とした。また，この時に脳動脈瘤のネック（入口）部分は直径 $4 \mathrm{~mm}$ とした．血管直径は 8 [mm]である. 3 D プリンター (UP Plus, OPT Technologies Co. , Ltd.) の積層ピッ チ，プリント精度は約 $0.15[\mathrm{~mm}]$ であり，上記脳動脈瘤の作成には十分な精度を持つ. 作成した ABS 樹脂モデル を図 6 (b) に示す。このモデルの動脈瘤部分と血管部分を分離し，それぞれを PDMS 樹脂にて型どりし，80 度で 2 時間硬化後，アセトンにて融解することでPDMS の脳動脈瘤モデルが作成される (図 6 (c)) . PDMS は柔軟性が あるため, ステントシートを図 6 (c) に示すように動脈瘤入口に配置し, 双方を治具で固定して力を掛けること で，漏れがなく流体を発生させることが可能である. 


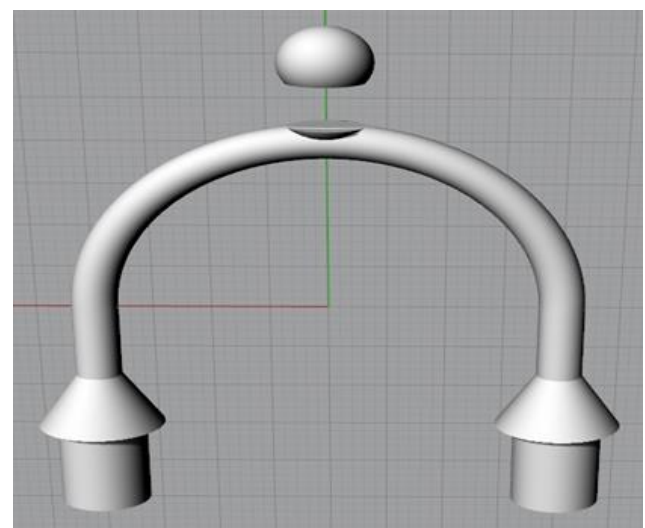

(a) 3 dimension model of aneurism

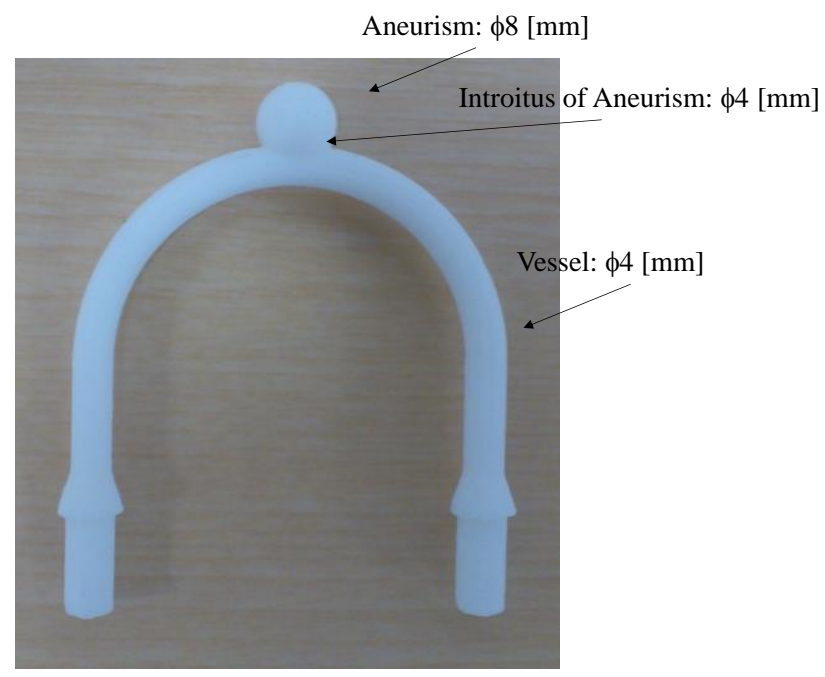

(b) Mold of the aneurism

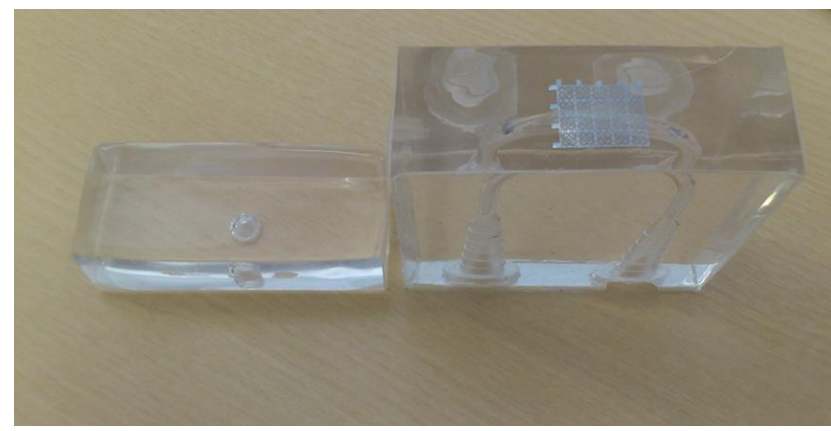

(c) PDMS model of aneurism

Fig.6 Experimental model of PIV. The mold is made by 3D printer. The stent sheet is attached between the an aneurysm and vessel.

\section{3・ 3 PIV 実験方法}

PIV 実験では，流体にパーティクル（微小物体）を混ぜ，それを拍動ポンプを用いて作成したモデルに流す。 モデルにレーザーを照射し，パーティクルに反射した光を高速度カメラで撮影することで流体の流れを観察す る. 実験装置を図 7 に示す. 拍動ポンプ (Harvard apparatus pulsatile blood pump 1405-048, Harvard Appartus CO., LTD. ) をモデルに接続し, 流れる流体には可視化用粒子として直径 $4 \mu \mathrm{m}$ のポリスチレンビーズ を混入している。レーザには YAG レーザ（イットビリウムファイバーレーザ YML-5-1064，IPG C0., LTD. ) を用 い，映像を高速度カメラ (Photron 1DP, Photron CO., LTD.) にて撮影している. 各実験条件を表 2 に示す. 


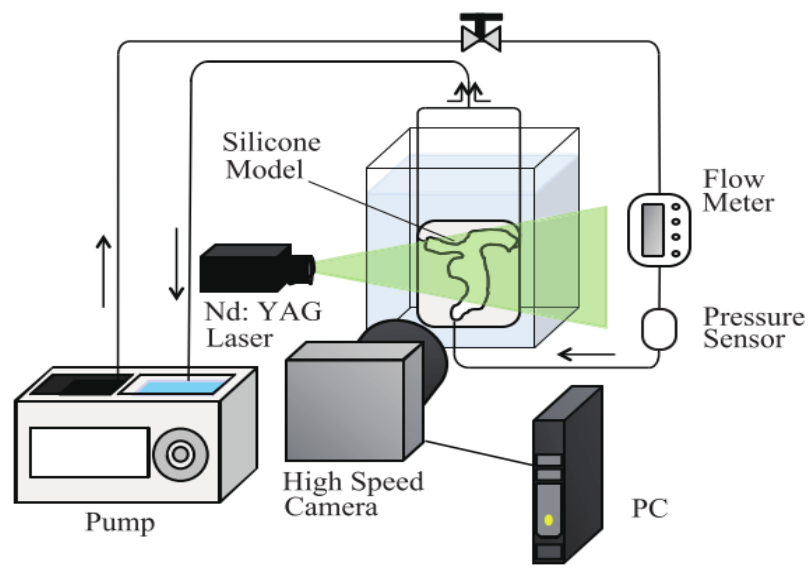

Fig.7 Experimental device. The high speed camera observe the particle patterns.

Table 2 Experimental condition

\begin{tabular}{|c|c|}
\hline Pump setting & $60[$ STROKES/MIN $]$ \\
\hline Frame rate of camera & $125[\mathrm{fps}]$ \\
\hline Density of particle & $2.0[\mathrm{~g} / \mathrm{L}]$ \\
\hline
\end{tabular}

\section{$3 \cdot 4$ 実験結果}

弁付きフラクタルステントを留置した場合と留置しない場合でPIV 実験を行った. 図 7 に示すシステムにて 作成したモデルにステントを入れる場合と入れない場合とで比較を行う。これを高速度カメラで取得する.

取得した動画を PIV 解析ソフト(DETECT. DipMotion2D)にて解析した．解析結果を図 8 に示寸．図 8 (a)は ステントなし，図８(b)はステントを挿入した計測結果である。 ステントがないモデルの最大流速は約 31 $[\mathrm{mm} / \mathrm{s}]$ で，ステントがある場合は約 $19[\mathrm{~mm} / \mathrm{s}]$ である。最大流速比では約 49\%の流入を防ぐことが実現し た．またステントが無いものについては動脈瘤内部を渦巻く様に，外周にまで流れが発生している．しかし ながら, ステントを入れることで外周の流れが抑えられ，中心部分にのみ流れが発生している.

以上の結果から，フラクタルステントにて動脈瘤への流体の流入が抑えられることが確認された. 
Ichikawa, Ito, Shimogaito, Kubo and Fukuda, Transactions of the JSME (in Japanese), Vol.81, No.830 (2015)

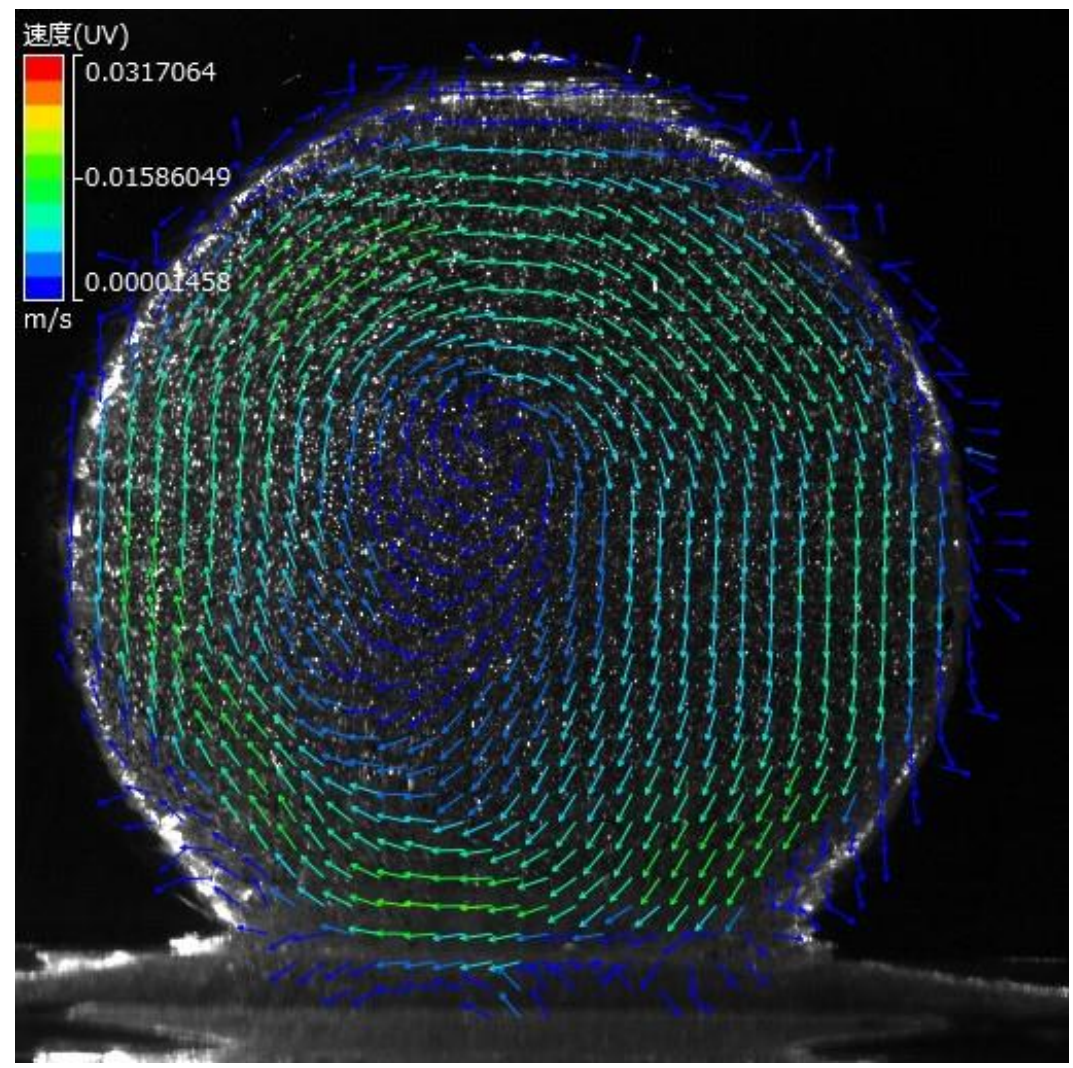

(a) Analysis result -no sutent-

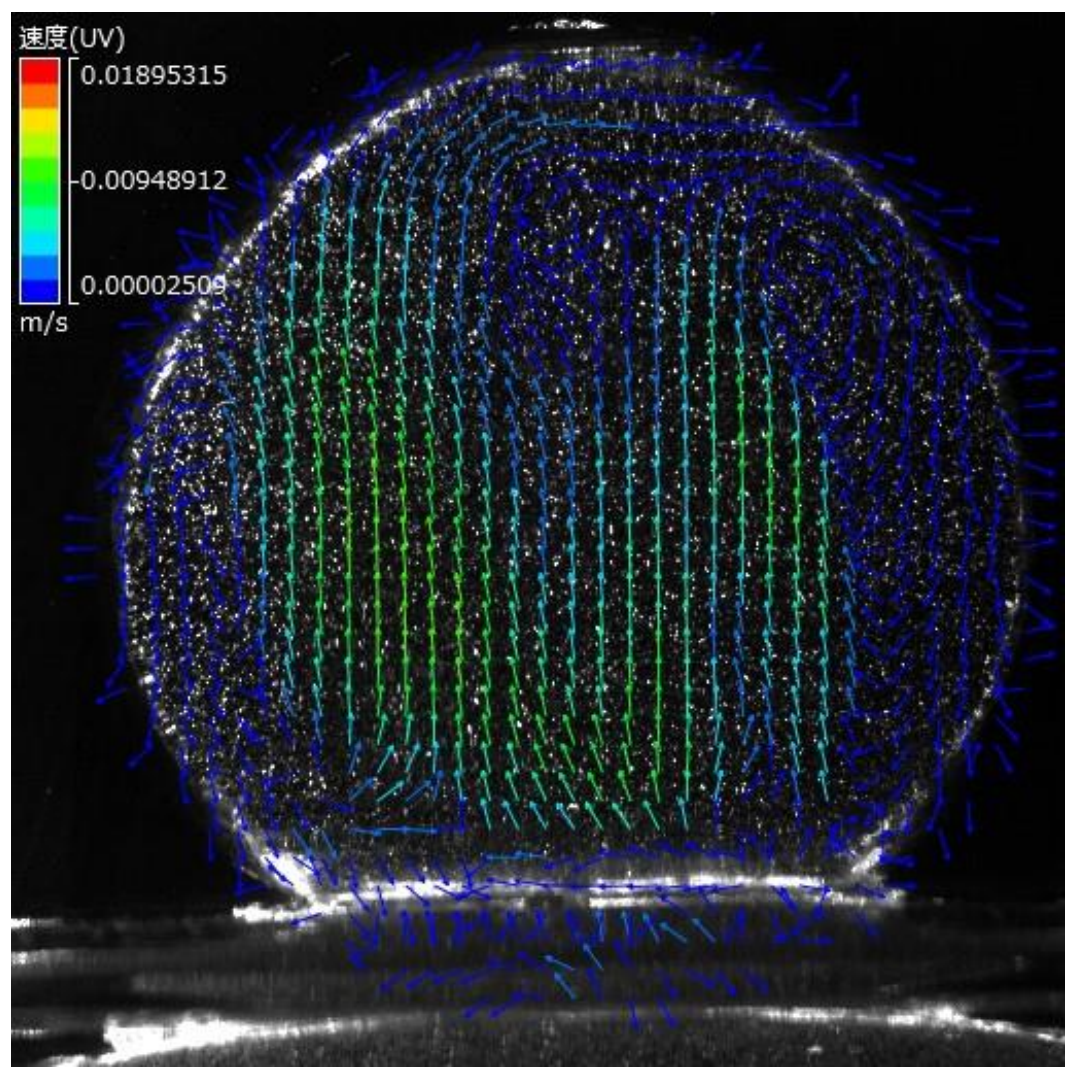

(b) Analysis result -with valve fractal stent-

Fig.8 Experimental result of the PIV. The flow is reduced to $55 \%$. 


\section{4. 結言}

本研究では，脳動脈瘤治療に対する新たな医療デバイスとして，弁付きフラクタルステントを提案する. 弁付 きフラクタルステントは，カテーテル挿入用の穴に開閉弁を取り付けた構造となっている. これにより，従来研 究のフラクタルステントの問題点であるコイル治療の併用を目的としたカテーテル挿入用の穴からの血液の流入 によるフローダイバータ効果の低下を解決した.

弁付きフラクタルステントの有用性を検証するために脳動脈瘤モデルを作成し，PIV 実験を行った。脳動脈瘤 モデルは，3D プリンタでモデルの型を作り，それを PDMS で覆うことで作成した．PIV 実験により，脳動脈瘤 モデル内の流体の流れを可視化した結果，弁付きフラクタルステントがモデル内への流体の流入をある程度抑え ていることが分かった．また，モデル内への流体の流入量を計算した結果，弁付きフラクタルステントは，モデ ル内への流体の流入を抑えることが出来た. これらの結果より，弁付きフラクタルステントは，脳動脈瘤知立に 対して有効であると言える.

今後の課題として，円筒状のステントでの流体実験，弁駆動実験，コイル挿入の確認のため，シート状の弁付 きフラクタルステントを円筒形状で作成する方法の確立，開閉弁のフラクタル形状の最適化による流体制御の向 上及び血管内皮細胞への早期埋没である.

\section{References}

Armoiry, X., Paysant, M., Hartmann, D., Aulagner, G. and Turjman, F., Interest of flow diversion prostheses in the management of unruptured intracranial aneurysms, International Journal of Vascular Medicine(2012), pp.1 - 5.

Benndorf, G., Herbon, U., Sollmann, WP. and Campi, A., Treatment of a ruptured dissecting vertebral artery aneurysm with double stent placement: case report, AMERICAN JOURNAL OF NEURORADIOLOGY., Vol.22, No.10(2001), pp.1844 $-1848$.

Doerfler, A., Wanke I., Egelhof, T., Stolke, D. and Forsting, M., Doublestent method: therapeutic alternative for small wide necked aneurysms, JOURNAL OF NEUROSURGERY., Vol.100, No.1(2004), pp.150 - 154.

Hurst, D. and Vassilicos, J. C., Scalings and decay of fractal-generated turbulence, Physics of Fluids., Vol.19, Issue.3(2007), DOI:10.1063/1.2676448.

Kim, Y. H., Xu, X. and Lee, J. S., The Effect of stent porosity and strut shape on saccular aneurysm and its numerical analysis with Lattice Boltzmann Method, Annals of Biomedical Engineering., Vol.38, Issue.7(2010), pp.2274 - 2292.

Kojima, M., Irie, K., Fukuda, T., Arai, F., Hirose, Y. and Negoro, M., The study of flow diversion effects on aneurysm using multiple enterprise stents and two flow diverters, Asian Journal of Neurosurgery, Vol.7, Issue.4(2012a), pp.159 - 165.

Kojima, M., Irie, K., Ikeda, S., Fukuda, T., Arai, F., Hirose, Y. and Negoro, M., The hemodynamic study for growth factor evaluation of rupture cerebral aneurysm followed up for five years, Journal of Biomedical Science and Engineering, Vol.5, Issue.12(2012b), pp.884 - 891.

Ku, D. N., Giddens, D. P., Zarins, C. K. and Glagov, S., Pulsatile flow and atherosclerosis in the human carotid bifurcation. positive correlation between plaque location and low oscillating shear stress, Arteriosclerosis, Thrombosis, and Vascular Biology. Vol.5, No.3(1985), pp.293 - 302.

Lubicz, B., Collignon, L., Raphaeli, G., Pruvo, J. P., Bruneau, M., De, W. O. and Leclerc, X., Flow-diverter stent for the endovascular treatment of intracranial aneurysms a prospective study in 29 patients with 34 aneurysms, Stroke, Vol.41, No.10(2010), pp.2247 - 2253.

Lylyk, P., Cohen, J. E., Ceratto, R., Ferrario, A. and Miranda, C. Endovascular reconstruction of intracranial arteries by stent placement and combined techniques, JOURNAL OF NEUROSURGERY. Vol.97, No.6(2002), pp.1306 - 1313.

Lylyk, P., Miranda, C., Ceratto, R., Ferrario, A., Scrivano, E., Luna, H. R., Berez, A. L. Tran, Q., Nelson, P. K. and Fiorella, D., Curative endovascular reconstruction of cerebral aneurysms with the pipeline embolization device: the buenos aires experience, Neurosurgery, Vol.64, No.4(2009), pp.632 - 642.

Malek, A. M., Alper, S. L. and Izumo, S. Hemodynamic shear stress and its role in atherosclerosis, JAMA-JOURNAL OF THE AMERICAN MEDICAL ASSOCIATION, Vol.282, No.21(1999), pp.2035 - 2042.

Mantha, A., Karmonik, C., Benndorf, G., Strother, C. and Metcalfe, R., Hemodynamics in a cerebral artery before and after the 
formation of an aneurysm. AMERICAN JOURNAL OF NEURORADIOLOGY, Vol.27, No.5(2006), pp.1113 - 1118.

Mehta, B., Burke, T. Kole, M., Bydon, A., Seyfried, D. and Malik, G., Stent-within-a-stent technique for the treatment of dissecting vertebral artery aneurysms, AMERICAN JOURNAL OF NEURORADIOLOGY, Vol.24, No.9(2003), pp.1814 - 1818.

Meng, H., Wang, Z., Hoi, Y., Gao, L., Metaxa, E., Swartz, D. D. and Kolega, J., Complex hemodynamics at the apex of an arterial bifurcation induces vascular remo- deling resembling cerebral aneurysm initiation, Stroke, Vol.38(2010), pp.1924 $-1931$.

Nagata, K., Sakai, Y., Inaba, T., Suzuki, H., Terashima, O. and Suzuki, H., Turbulence structure and turbulence kinetic energy transport in multiscale/fractal-generated turbulence. Physics of Fluids, Vol.25, Issue.6(2013), DOI:10.1063/1.4811402.

Nelson, P. K., Lylyk, P., Szikora, I., Wetzel, S. G., Wanke, I. and Fiorella, D., The pipeline embolization device for the intracranial treatment of aneurysms trial. AMERICAN JOURNAL OF NEURORADIOLOGY, Vol.32, No.1(2011), pp.34-40.

Seoud, R. E. and Vassilicos, J. C., Dissipation and decay of fractal-generated turbulence. Physics of Fluids, Vol.19, Issue.10(2007), DOI:10.1063/1.2795211.

Shimogonya, Y., Ishikawa, T., Imai, Y., Matsuki, N. and Yamaguchi, T., Can temporal fluctuation in spatial wall shear stress gradient initiate a cerebral aneurysm? A proposed novel hemodynamic index, the gradient oscil- latory number (GON), JOURNAL OF BIOMECHANICS, Vol.42, No.4(2009), pp.550 - 554.

Szikora, I., Berentei, Z., Marosfoi, M., Vajda, Z. S., Lee, W., Berez, A. and Nelson, P. K., Treatment of intracranial aneurysms by functional reconstruction of the parent artery: the budapest experience with the pipeline embolization device, AMERICAN JOURNAL OF NEURORADIOLOGY, Vol.31, No.6(2010), pp.1139 - 1147. 